\title{
ASTN2 wt Allele
}

National Cancer Institute

\section{Source}

National Cancer Institute. ASTN2 wt Allele. NCI Thesaurus. Code C82895.

Human AST N2 wild-type allele is located in the vicinity of 9q33.1 and is approximately 990 $\mathrm{kb}$ in length. This allele, which encodes astrotactin-2 protein, may be involved in neural development. Copy number variation for the gene is associated with schizophrenia and autism. 